\title{
Spanish Adult Students' Intention- BEHAVIOUR TOWARD MOOCS During The COVID-19 PANDemic
}

\author{
LA INTENCIÓN Y COMPORTAMIENTO DE ESTUDIANTES ADULTOS ESPAÑOLES \\ FRENTE A LOS MOOC DURANTE LA PANDEMIA DE COVID-19 \\ A intenção e Comportamento de estudantes adultos eSPanhóis Frente aOS MOOC \\ DURANTE A PANDEMIA COVID-19
}

\author{
Maria Ángeles Escobar Álvarez \\ Full Professor, Universidad Nacional \\ de Educación a Distancia (UNED), \\ Madrid, Spain. \\ maescobar@flog.uned.es \\ https://orcid. \\ org/0000-0001-8650-0038

\section{Julie Ciancio} \\ Chief Academic Officer, Westcliff \\ University, Irvine, CA, USA. \\ julieciancio@westcliff.edu \\ https://orcid. \\ org/0000-0003-2497-8612
}

\begin{abstract}
Many Spanish students need to learn English beyond the age of 25 to be able to find a job or be further promoted. Unfortunately, those who attempt to pass a university entry-qualifications test often lack the required academic level. To help them achieve this goal, they are usually provided with learning materials and supportive digital resources. During the COVID-19 pandemic, the need for online resources increased. This is why the National Distance Education University offered a massive open online course (MOOC) on elementary English. The main goal of this contrastive qualitative study was twofold: First, it attempted to explore adult students' intention-behaviour while taking the course. Secondly it delved into students' satisfaction with this type of courses during two different years: 2017 and 2020 when the pandemic had a clear impact on distance education. For this purpose, the study used a comprehensive post-questionnaire given at the end of both courses. The data revealed a few significant differences regarding students' satisfaction, intentions, perceptions, and interests in contexts where face-to-face-learning was not an option. These findings suggest that Mooc should be considered as an alternative way to build specific content in situations of crisis.

Keywords: MOOC; COVID-19; intention-behaviour; students' needs; ICT; EFL; adult students; brief-learning courses.

\section{RESUMEN}

Muchos estudiantes españoles se ven en la necesidad de aprender inglés después de los 25 años para poder acceder a un empleo o lograr un ascenso. Lamentablemente, aquellos que intentan aprobar un examen de admisión a la universidad por lo general carecen del nivel académico requerido. Para ayudarles con este objetivo, en general, se les proporciona materiales de aprendizaje y recursos digitales de
\end{abstract}

Received: 2021-01-18 / Accepted: 2021-06-17 / Published: 2021-09-11

https://doi.org/10.17533/udea.ikala.v26n3a04

Special issue on The Role of Technology in Language Teaching and Learning amid the Crisis Generated by the COVID-19 Pandemic. Editors: Marta González-Lloret, University of Hawai'i at Mānoa, UsA; Laia Canals, Universitat Oberta de Catalunya, Spain; Jorge Pineda, Universidad de Antioquia, Colombia.

(C) 2021 Universidad de Antioquia. This is an open access article distributed under the terms of the Creative Commons License BY-NC-SA 4.0 International. 
apoyo. Durante la pandemia del Covid-19, aumentó la necesidad de recursos en línea. Para llenarla, la Universidad Nacional de Educación a Distancia lanzó un curso masivo en línea abierto (MOоc) de inglés básico. El objetivo principal de este estudio cualitativo comparado fue doble: en primer lugar, intentó explorar las intenciones y el comportamiento inicial de los estudiantes adultos al tomar ese curso y en segundo lugar, trató de profundizar en la satisfacción de los estudiantes con este tipo de cursos durante dos años diferentes: 2017 y 2020, año en que la pandemia tuvo un impacto evidente en la educación a distancia. Los datos se recolectaron mediante un cuestionario que se pasó a los participantes al final de cada curso. Los resultados obtenidos revelaron algunas diferencias significativas respecto a la satisfacción de los estudiantes con el curso, a sus intenciones, percepciones e intereses en contextos de aprendizaje donde la enseñanza presencial no era una opción. Esto implica que el diseño de MOoc debe considerarse como una alternativa para construir conocimiento específico en situaciones de crisis.

Palabras clave: MOOC; COVID-19; comportamiento e intenciones; necesidades de los estudiantes: TIC; ILE; estudiantes adultos; cursos breves de contenido específico.

\section{RESUMO}

Muitos estudantes espanhóis precisam aprender inglês depois dos 25 anos de idade, para poder encontrar um emprego ou ascender ainda mais no seu local de trabalho. Aqueles que tentam efetuar uma prova de acesso à universidade, geralmente não têm a preparação suficiente para passar uma prova de qualificação de ingresso à mesma. Por isso, as universidades geralmente oferecem materiais de aprendizagem e recursos digitais de apoio. Durante a pandemia do CoviD-19, os estudantes precisaram de mais recursos on-line. Para isso, a Universidade Nacional de Educação à Distância tem oferecido um curso aberto, massivo e online (MOOC) de inglês básico. $\mathrm{O}$ objetivo principal do estudo de um curso intensivo de inglês elementar foi duplo: em primeiro lugar, ele tentou explorar o interesse inicial dos estudantes adultos enquanto frequentavam o MOOC, e no segundo lugar, focouse na satisfação dos estudantes com este tipo de cursos nos anos 2017 e 2020. Este último em que a pandemia teve um claro impacto na educação à distância. Os dados foram coletados por meio de um questionário que foi repassado aos participantes ao final de cada curso. Os resultados revelaram algumas diferenças significativas em relação à satisfação do aluno com o curso, às suas intenções, percepções e interesses, contextos de aprendizagem onde o ensino presencial não era uma opção. Isso implica que o projeto de cursos intensivos LMOoc deve ser considerado como uma forma alternativa de construir um conteúdo específico em situações de crise.

Palavras-chave: MOOC; COVID-19; comportamento e intençóes; necessidades dos estudantes; TIC; EFL; estudantes adultos; cursos intensivos de conteúdo específico. 


\section{Introduction}

With the crisis generated by the COVID-19 pandemic, the role of technology in language teaching and learning has played a relevant role in distance education because it has expanded the teacher's ability to deliver new forms of multimodal discourse combining texts, podcasts, images or video, and the potential of massive open online courses (MOOC) is a case in point. They can offer large-scale interactive participation in the target language using open access via the web. Higher education institutions both in the public and private sectors are interested in carrying out MOoc design and implementation, particularly when face-to-face learning is not an option, as is the case now in many higher education institutions around the world (Bárcena \& Read, 2015). Moreover, MOoc designers are especially interested in learning more during this unique opportunity since they may test the validity of their courses regarding student needs on a larger scale than normal. In this regard, the present study aims to test how quality content and technological tools aim to meet student needs in a MOOC intended as a vehicle for second-language learning.

It is commonly believed that motivation plays a substantial role in second-language acquisition, and a deeper understanding of student needs may help to reveal more about why some language learners learn more easily than others (Carrió-Pastor \& Mestre Mestre, 2014). For example, diverse learning styles in higher education might lead to alternative methods of instruction and assessment that better match students' preferences surrounding language learning and the development of more effective teaching and learning practices (Grünewald et al., 2013). The data discussed are typical in the use of questionnaires regarding learners' goals and preferences as well as their intention to take a course such as a language Mooc.

The mooc presented in this study was relaunched in the pandemic as part of the Spanish Distance Education University's (UNED) strategy to develop sustainable distance teaching programs suitable for social and economic development. In order to measure students' intention-behaviour gap and their satisfaction regarding quality content and technological tools, this study aimed to compare data obtained from a survey taken by students enrolled in the MOOC during the first edition in 2017 with those found in the special edition offering of the MOOC during the COVID19 pandemic in 2020. Following UNED Abierta guidelines, we use the term "edition" together with the year for the courses examined since they have similar content.

\section{Theoretical Framework}

This section deals with some literature review concerning the concept of MOocs since they have recently underlined a process of transformation and settlement at both secondary and tertiary education levels.

\section{Digital Learning and Moocs}

Much research has been done on the benefits of learning for students from diverse backgrounds and age groups enrolled in Moocs. Brahimi and Sarirete (2015) noted the tendency of MOocs to appeal to learners from various ages, learning contexts, countries, interests, and abilities. Koller et al. (2013) pointed out the benefits to learning in MOocs despite retention rates, challenging traditional concepts of assessment and course completion. Liyanagunawardena and Williams (2016) reported that elderly learners are also engaging at a significant rate in MOocs. There has been a lack of research into understanding age difference and participation in MOocs (Liyanagunawardena \& Williams, 2016; Torres \& Beier, 2018). However, age may not be the crucial factor in determining learners' motivation. Studies by MOOC providers have recently focused on other relevant factors determining their learners' interest. For example, Walker (2018) reported different learners on the digital education platform FutureLearn in terms of behavioral archetypes regarding common human behaviour, typical attitudes, motivation, 
and similar goals. Likewise, the first objective of this paper is to discuss, from a pedagogical perspective, the type of adult learners that take MOOC courses launched by UNED, a Spanish distance education university.

So far, research on digital learning through Moocs in higher education has put forward their potential to make high-quality teaching accessible to everyone with internet access (Grünewald et al., 2013). Indeed, one distinct aspect of these open-learning systems includes diminished impediments to enrollment; moreover, an analysis of learning analytics can aid in telling a more complete story of the benefits of open digital learning (Wedemeyer, 1973; Wong, 2019). The main goal of these courses is to bring together thousands of learners who are attracted to a common learning project; nevertheless, specific courses and learners largely differ with respect to their final goals (Jung et al., 2019).

Possible motivations for entrance into Moocs could include individual demand, broader intellectual improvement, acquiring employability skills and possible exposure to prospective subject matter for future study (Breslow et al., 2013; Christensen et al., 2013; Gütl et al., 2014; Hew $\&$ Cheung, 2014). Some participants may take a MOOC course to complement additional learning in a formal setting. For example, it was noted that university learning provides both formal and informal learning opportunities that can include MOOCs as informal learning support (Pankowska, 2017); however, further research is still needed to determine how learning outcomes may vary for users based on their motivations for supplemental learning through Moocs (Universities UK, 2013). Some users may want to enroll in a MOOC to interact with people of common interests. Social connections, a desire to engage with other like-minded individuals around the world and learning about peers' experiences and perspectives were also cited as driving factors in learners' motivation to join a MOOC (Loizzo et al., 2017).
Following Pilli and Admiraal (2016), we may distinguish among types of MOocs offered by different open institutions. In particular, we can distinguish between MOocs, relying on some text materials supplemented with interactive exercises and discussion boards, and more social-oriented Moocs based on open educational resources in which participants play a more relevant role by constructing their own learning process through crucial interaction with others, as expected by connectivist pedagogy (Siemens, 2005). Due to the flexible nature of this second type of MOOC, which has an epistemological foundation based on connectivism, it is commonly referred to as a cMOOC (Zapata-Ros, 2013).

This adaptability of Moocs is also one of their greatest benefits, allowing users to participate based on connection regardless of location, age, and other factors (Brahimi \& Sarirete, 2015). Moreover, Anders' (2015) study suggested that hybrid MOocs, such as those that are community or task-based, are able to reach the greatest diversity of learners and also help to address the issue of a loss of users and unequal participation over time.

Finally, other new types of MOocs targeting other specific goals are being developed (Castrillo de Larreta Azelain et al., 2018). Even if the technology and heutagogy surrounding these types of open learning systems advance, it seems that the current false dichotomy of xMOOCs and cMOOCs is inadequate to describe the variety of MOocs that are currently available to users (Canole, 2016). Another type of MOOC that can take advantage of and combine formal and informal learning while promoting improvement of reciprocal and practical interactions that could be lost in other language-learning contexts are Language Moocs (Bárcena \& Read, 2015), discussed more in the following section.

\section{Language Moocs}

Since MOOC courses are especially useful when meeting specific requirements of learners, 
language researchers, attempting to meet the needs of language teachers, have put forward a type of MOOC containing features of brief language courses. In this sense, the so-called LMOocs crucially pay respect to the roles and methodological strategies of online language teachers (Martín-Monje \& Bárcena, 2014; Bárcena et al., 2015; Castrillo de Larreta Azelain (2015). Currently, course organization is a central focus of online language teaching. Following Bárcena and Read (2015), modularly organized LMoocs hold advantages for diverse groups of learners because they can offer more activities than necessary for most users while having students only complete a certain percentage of the total.

According to Castrillo de Larreta Azelain (2015), the teacher should work as a structure designer or content generator in an LMOOC, being engaged in four important steps, including dividing the course into modules of units, (over)estimating the hours of study involved in the MOOC, setting mastery standards for each unit, differentiating between obligatory and optional tasks, and including a proposed timeline with an ordering of content. Bárcena et al. (2015) discussed the "human dimension" of LMOOCs and noted that new teaching methods should create learning experiences that can be approachable and acceptable to students of differing personality profiles and cognitive abilities. Furthermore, the role of the teacher as a facilitator in LMOocs cannot be overlooked since this is key for the educational integration of these types of open courses (Mengual-Andrés \& Payà Rico, 2018).

\section{Intention-Behaviour Gap}

As discussed by recent research, such as in Sheeran \& Web (2016), the concept of intention has also proved essential, and some interventions are specifically claimed to promote public health, energy saving, as well as educational and organizational outcomes. Some studies indicate that intentions predict specific behaviour. Most ordinary-life behaviour is expected when provided with ordinary situational cues (Bargh, 2006; Wood \& Neal, 2007). However, in extreme situations like the current COVID-19 pandemic, the students' intentions may result in unexpected behaviour, and forming new intentions can be crucial for securing long-term goals (Baumeister \& Bargh, 2014; Kuhl \& Quirin, 2011). Indeed, there are emerging studies of different academic approaches to respond to emergency eLearning as an essential alternative to face-to-face schooling in many universities around the world (Escobar \& da Cunha, 2018; Kenny \& Escobar, 2020).

The study discussed in the following section addresses the intention-behaviour gap in educational contexts regarding LMOOCs launched in different social situations. In particular, it frames the responses of an emergency LMOOC launched by a Spanish university. It also provides a more in-depth analysis of students' responses to these types of courses and considers their utility in educational contexts extended to digital learning in future contexts after the COVID-19 pandemic.

\section{Common Challenges Encountered With Moocs}

Despite the potential of Moocs for global digital education, a few challenges have been emerging, especially those related to foreign language learning. Hakim (2020) noted that some common challenges faced by online language teachers during the pandemic include the inability to access modern equipment, problems with internet connection, learners' low levels of motivation and attention deficit. The course completion rate of MOOCs is a challenge affected by numerous variables. Zhang et al. (2019) indicated that academic program alignment with student needs, English proficiency, and motivation all can contribute to the likelihood of MOOC completion. Another common obstacle for elementary language Moocs lies in learners' low level of English language skills. In addition, the brevity of this type of course makes it difficult to provide materials with authenticity and communicativeness. It is 
difficult to include a complete teaching method, regardless of whether it encompasses several activities under different skill or genre-oriented approaches. Self-motivation can also be difficult for learners, particularly during a pandemic, so exploiting the social nature of Moocs through group work and connectivist activities can help to ease and even overcome this challenge. The emphasis on inclusiveness combined with mastering some discipline-specific knowledge can result in clear benefit from MOocs.

The present MOoc framework might facilitate instructors attempting to address student needs concerning one particular purpose: to help them pass the English language university entry-qualifications test. Therefore, we include discipline-specific knowledge that is typically tested there: basic grammar, use of vocabulary and reading skills. While grammar is not always considered a practical ingredient in courses adopting a communicative approach, we adopt it as essential for our MOOC because it is part of the content on the entry-qualifications test which measures language proficiency levels.

In this study, we examine the responses to a pair of questionnaires completed by two groups of adult learners who had undertaken the course at different times: in late 2017 and in 2020, during the global pandemic of Covid-19. By analyzing students' responses to these questionnaires, we attempt to see the relevance of LMOOC courses among adults after having completed the course in two different human situations: ordinary and pandemic. In brief, we raise two main questions: (1) Can a MOOC course meet the human intention to learn, in other words to study and find something new that has not been seen or thought or discovered before? (2) Can a MOoc course similarly help to satisfy students' L2 needs and provide them with the most appropriate resources to optimize academic performance in both ordinary and pandemic situations? Since our study includes two different groups of adult learners according to the course year of the LMOOC when they were enrolled, either in 2017 or in 2020 (covid19 pandemic special edition), we find ourselves in the unique position to also compare their motivation and preferences in these very different social backgrounds (ordinary and pandemic). By doing so, we have been able to contrast their responses and predict in future situations the importance of LMOOCs for digital learning that can be extended across borders.

\section{Method}

Research on intention behaviour frequently makes use of questionnaires to elicit data. Our questionnaire had two parts (see Appendix). The first part included similar questions found in other MOocs at UNED Abierta to obtain data regarding students' initial intentions, and therefore, test validity was confirmed. The second part of the questionnaire, at the end of the course, included common questions found in other UNED MOOC to test students' satisfaction with respect to course contents (GilJaurena et al., 2017). In addition, we also included similar questions to those found in the first part of the questionnaire to test whether respondents' initial intentions were reaffirmed after taking the MOoc. The same questionnaire was previously administered in 2017 when students showed to have understood the questions, supporting their reliability.

\section{Participants}

The data concerning the main characteristics of participants was provided by the initial test, which was administered at the beginning of both LMOOCs. Altogether, the majority of course participants were aged in their 30 s or 50 s (each approximately $28 \%$ ). Nearly $30 \%$ belonged to the group in their 30s, and a remarkably high 55\% came from the group above 40 years. The remaining $15 \%$ were students of 30 years and younger. Since the LMOOC course focused on English grammar topics, we also asked for a self-assessment of our users' background in English upon registration: approximately $60 \%$ of participants 
described themselves as having a very low level (A1) of English, 32\% declared themselves as beginners (A2), and 18\% identified as intermediate (B1).

From the final experimental questionnaire delivered to all of the approximately 3,000 registered participants in the first LMOOC, we obtained over 500 questionnaire responses, and with over 1,200 registered participants in the special edition LMOOC, we obtained over 120 responses. These responses allowed us to understand the motivations, conditions, and expectations for taking part in the course in both ordinary and pandemic situations, and to obtain a high number of valuable suggestions for improving the course content and format in the future. The experiment design followed all research standards and abided by normative practices in the country where the experiment took place.

\section{LMOoc Design}

For the purpose of our study, we attempted to design an LMOOC following the ideas put forward in current research. However, we did not draw on the beneficial implications of LMOocs for language teachers. Rather, we paid closer attention to students' L2 needs in this type of course. In fact, our LMOOC course was part of a larger online program of English as a second language that prepared mature learners for university entry-qualifications tests. When designing the LMOOC, not only did we look for purely theoretical learning content, but we also invited learners to relate and apply the knowledge to their future needs. Interestingly, our LMOOC turned out to be very attractive to many other adult learners, as seen in the discussion of the results of our study.

The goal of the first edition of the LMOoc, launched in late 2017, was twofold. First, it would support a formal online English course (elementary level) offered by UNED to students over 25 years old, who wanted to get trained for the university entry-qualification test. Secondly, it would highlight the four skills of this university entrance exam: reading comprehension, use of English, vocabulary, and writing. In short, the LMOOC included video clips with some guidelines followed by a few traditional exercises addressing listening, reading, and writing practice, like those exercises found in those tests through an intensive five-week program. The course ended with an optional post-questionnaire about learners' expectations and preferences for this type of LMOOC course in the context of learning English as a second language.

Eventually, the same LMOOC was offered as part of an open program to adults that wanted to keep learning from home due to confinement during the COVID-19 pandemic from March to June 2020. In this case, the main goal was to test the importance of LMOoCs in extreme social situations like our current one. News sources, governments, and scientists affirm that we will not return to our previous lives because we will have a "new normal," and its effects will be very important in the global academic sector. What will that new situation be like? Will its effects continue in the long term? We must consider different scenarios, but, in the short-term, the effects will be decidedly relevant. In our study, we wanted to test whether an LMOOC can maintain learning curiosity and motivation.

The LMOOC course lasted 5 weeks and included 4 modules, each taught by a different instructor. The first module was about the importance of learning a second language and its widely recognized benefits such as augmenting social life and enhancing work promotion. The second module included some basic concepts of English grammar fundamentally dealing with word order and highlighting the basic properties of nouns, verbs, and clauses. The third module largely focused on reading comprehension in a second language. It included a short English text followed by multiple-choice questions. The fourth module was about writing in the second language, where some 
key linking words were introduced to show how to write a coherent paragraph.

All modules included short video clips in the form of learning "pills" (Martín-Monje \& Bárcena, 2014), recorded by each module instructor. Related exercises followed all learning video clips to let participants practice and assess their own understanding of each course module. The LMOOC ended with some specific information about how to deal with the entry-qualifications test, with an extra learning video in which an instructor provided students with a mock test and some examination tips. After the course, participants could freely complete a questionnaire that we used as part of the current study. The final LMOOC structure is given in Table 1.

Table 1 Lmooc Structure (L2 English for EntryQualifications Test)

\begin{tabular}{|c|c|c|}
\hline Modules & Learning Pills & Activities \\
\hline $\begin{array}{l}\text { 1. English Courses } \\
\text { for Adults }\end{array}$ & $\begin{array}{l}\text { 1. Advantages, } \\
\text { Methodology and } \\
\text { Materials }\end{array}$ & $\begin{array}{l}\text { Pretest } \\
\text { Forum }\end{array}$ \\
\hline $\begin{array}{l}\text { 2. Basic Aspects of } \\
\text { English Grammar }\end{array}$ & $\begin{array}{l}\text { 2. Basic Notions of } \\
\text { Nouns, Verbs and } \\
\text { Clauses }\end{array}$ & $\begin{array}{l}\text { Exercises } \\
\text { Forum }\end{array}$ \\
\hline 3. Reading: Basics & $\begin{array}{l}\text { 3. Acquiring } \\
\text { Vocabulary }\end{array}$ & $\begin{array}{l}\text { Exercises } \\
\text { Forum }\end{array}$ \\
\hline 4. Writing: Basics & $\begin{array}{l}\text { 4. Expressing } \\
\text { Discourse } \\
\text { Relations }\end{array}$ & $\begin{array}{l}\text { Exercises } \\
\text { Forum }\end{array}$ \\
\hline
\end{tabular}

Finally, students could do some additional research by browsing through a list of sources while working on each module. These resources ranged from web resources to online free dictionaries used freely as those indicated in Table 2.

To provide students with some help for the entryqualifications test, the course ended with an extra learning pill in which an instructor provided
Table 2 LMOOC Websites

\begin{tabular}{llll}
\hline Focus & Practice & Vocabulary & Pronunciation \\
\hline URLS & Websites for & Online & Phonetics \\
& English & dictionaries & https://canal. \\
& https://www. & https:// & uned \\
britishcouncil.org. & dictionary. & .es/series/5a7 \\
& tr/en/english/ & cambridge. & ae069bll \\
& mooc & org/es-LA/ & $11 f 72578 b 456 f$ \\
& & dictionary/ & \\
& & english/ & \\
Focus & Reading & Grammar & Listening \\
URLS & https:// & https://www. & https://lear- \\
& learnenglishteens. & grammarly. & nenglishteens. \\
& britishcouncil.org/ & com & britishcouncil. \\
& skills/reading/ & & org/skills/ \\
& elementary-a2- & & listening \\
& reading & & \\
\hline
\end{tabular}

students with a mock test and some examination tips. After the course, participants could freely complete the questionnaire. As for the communication with students, a group of 5 external facilitators were in charge of the forums created for each particular module. For low-level participants, online language forums were very convenient since they gave learners the flexibility to practice and ask the questions they had throughout the course, and the facilitators could address their questions about specific content and exercises as those mentioned in the LMOOC structure in Table 1, as well as for those web resources found in Table 2.

Through an intensive five-week course, students could practice the five modules described above. They were also encouraged to express their expectations concerning LMOOCs through the questionnaire at the completion of the course. In the first edition LMOOC in late 2017, this would initially serve to collect the data concerning students' intention-behaviour gap, learning curiosity and motivation to take the course. Eventually, the same questionnaire was included in the special edition LMOOC in March 2020; therefore, we could also obtain information about participants' 
preferences regarding the type of content exhibited in the LMOOC during very different social circumstances.

For the purpose of the current study, we attempted to analyse learners' perceptions of their L2 needs while attending this brief course during the COviD19 pandemic. In addition, the study could test the null hypothesis that there were no significant differences regarding the LMOOC questionnaire results of the pre and post-pandemic courses regarding the average intention-behaviour rate, provided that all modules were completed equally.

\section{Data Collection}

In order to collect data regarding participants' preferences and needs with respect to both LMOOC editions, a two-fold survey was included at the end of the course in which we could raise our experimental queries in a final questionnaire. In the first place, we wanted to know about the reasons why participants chose our LMOOC course, paying particular attention to their initial intentions either for general interest, research purposes, or just curiosity about this type of course. Secondly, we wanted to know what type of contents participants expected to find in an elementary English course: a traditional grammar-based method or a tailor-made course with vocabulary or contents for specific professional purposes.

In particular, a total of 12 informative questions were posed: 6 questions regarding participant's intention-behaviour, and another set of 6 statements relating to students' expectations regarding the type of course contents for an LMOoc like ours. For the purpose of this paper, the different questions have been translated into English and discussed in the next two subsections below.

\section{Questions About Participants' Intention-Behaviour}

The first part of the experimental questionnaire included questions about participants' intentions. Roughly speaking, the course was assumed to be taken by two groups of students: those who expected to take the final university entrance exam, and those who took the course for different reasons. The main purpose of the questionnaire was to measure participants' intentions while taking the LMOOC. In other words, we wanted to analyse the question of how consistent their goals were with their behaviour while living in an ordinary academic situation (LMOOC 2017), and contrast this to their goals and behaviour during the pandemic (LMOOC 2020). Consequently, we were looking for an intention-behaviour scale that could measure participants' intentions at two different points of time. The following list includes the specific post-test questions raised to measure participants' intentions.

\section{Questions on Intention Behaviour}

a. I have "browsed", although I have not seen the materials and activities in depth.

b. I have confirmed my level of English.

c. I have compiled materials on English grammar.

d. I have completed the course and made the best of it according to my L2 needs.

e. I have improved my results in English in the entry-qualifications course.

f. I have improved my English to pass the entryqualifications test.

Considering the questionnaire items listed above, a number of corresponding categories were considered per each question mapping each intention (see Appendix for the entire questionnaire).

\section{Categories Mapping Intention-Behaviour}

a. Just browsing through the course

b. Confirming my level of English

c. Compiling English grammar materials

d. Meeting student L2 needs

e. Helpful for the entry-qualifications course

f. General L2 improvement

Thanks to the responses of the final questionnaires delivered to all participants in both groups, we were able to understand students' motivations, conditions and expectations for taking part in 
the course in both ordinary and pandemic situations, and to obtain a high number of valuable suggestions for improving the course content, and format in the future.

\section{Questions About Participants' Course Expectations}

A set of seven statements were included to determine students' opinions regarding the two types of courses addressing English grammar and vocabulary, on the one hand, and English for specific purposes (ESP), on the other. These statements, from which students had to choose according to their preferences, have been translated into English as follows.

\section{Questions on LMOOC Content}

a. University access English courses should primarily address grammar issues.

b. English courses for the entry qualifications test should contain vocabulary and specific content on different disciplines: law, mathematics, engineering, etc.

c. English courses for the entry qualifications test should explain the grammatical contrasts between English and Spanish.

d. English courses for university access should introduce you to the practice of the different professions in English.

e. The textbook titled "English Course for Adults" from UNED is helping me study English grammar.

f. The textbook titled "English Course for Adults" from UNED is helping me study English grammar.

g. The textbook "English Course for Adults" from UNED is helping me learn about different professional activities in English.

In order to measure the previous statements, we established a number of corresponding categories. The purpose of these was to map the following students' perceptions on course contents. From a pedagogical point of view, it was relevant to know whether students were aware that modern English courses may address different target audiences.

\section{Student Perceptions of LMOOC Contents}

a. English grammar

b. ESP content and vocabulary

c. Contrastive grammar

d. CLIL contents

e. Textbook CLIL contents

f. Textbook English

For example, considering English for specific purposes (esp content and vocabulary), in the context of Student Perceptions of LMOoc Contents, we wanted to know whether students expected to learn English as a second or foreign language, providing that esp usually refers to teaching the English language to university students or people already in employment, with reference to the particular vocabulary and skills they need (Hutchinson \& Waters, 1987; Kenny et al., 2020). In addition, we also wanted to see whether students expected to find an approach for learning content through an additional language (foreign or second). That is, if they expected to learn both the subject content and the language, as is the case with most Content and Language Integrated Learning (CLIL) courses (Thompson \& McKinley, 2018; Escobar, 2020).

\section{Results}

In order to score students' answers for all the questionnaire items discussed above, we used a binary scale for each of them (Yes: 1 point / No: 0 points). In this way, we could measure the linearity of the response in each group. All the questionnaire items can be found in the appendix for the sake of clarity.

\section{General Course Satisfaction}

First of all, we used a binary-scale design to control student's general satisfaction and possible recommendation of the course. The items in the questionnaire related to course satisfaction are listed below.

\section{Items on General Course Satisfaction}

a. The course has met my expectations to understand the necessary grammar for the entry qualifications test. 
b. I will recommend this MOoc to family, friends, and acquaintances.

On the one hand, we wanted to compare students' general satisfaction with the course in both years 2017 and 2020. Figure 1 includes students' responses to the two main questions rating general satisfaction and future recommendation of the mooc launched in 2017.

According to the findings depicted Figure 1, most participants showed to be satisfied with the course and responded to be willing to recommend the course to friends and relatives. On the other hand, we wanted to see whether we obtained similar

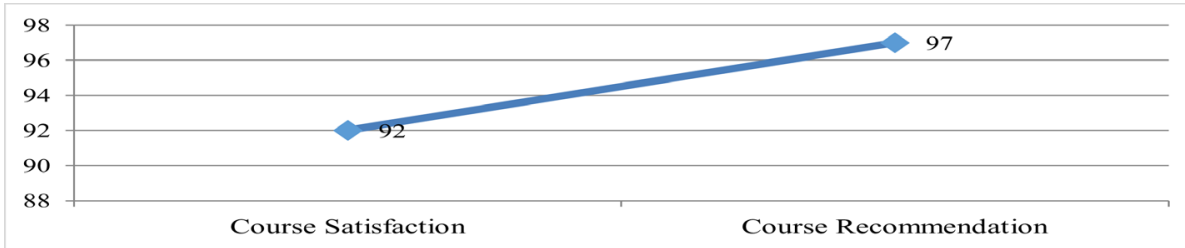

Figure 1 General Satisfaction and Recommendation (LMOoc 2017)

data from the students enrolled in the LMOOC launched in 2020 during the COVID-19 epidemic. As indicated in Figure 2, the data obtained in this second case shows a slightly higher number of students to be satisfied with the course compared with the first LMOOC, whereas a similar number of students responded that they were willing to recommend the course to friends and relatives.
In what follows, we consider the data concerning both students' intentions and perceptions regarding the contents for this type of LMOOC for an elementary English-based course. We present the mean responses per group in a contrastive manner to compare the data obtained from the questionnaires included in both LMOOC years (2017 and 2020).

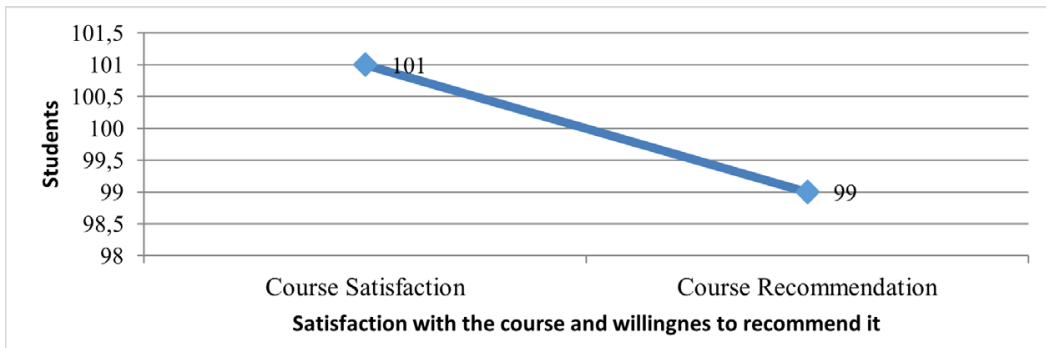

Figure 2 General Satisfaction and Recommendation (LMOOC 2020)

\section{LMOOC-2017 Results}

Nearly 500 students (out of 3,000 course participants) responded to the experimental questionnaire in the first LMOOC offered in 2017. For the purpose of our study, we took 122 students at random out of the first group to contrast their responses with those provided by the same number of students? from the second group of participants who took the LMOOC in 2020.
To begin with, we scored LMOoc participants' intention-behaviour using the first six statements regarding their perceptions of their attitudes towards the course they took in 2017. We assigned 1 for each selected statement and 0 when the statement was not selected. The total score is shown in Figure 3. As can be seen, most students chose confirming English level, and very few students show just browsing. In addition, many participants chose meeting their needs and expectations, 


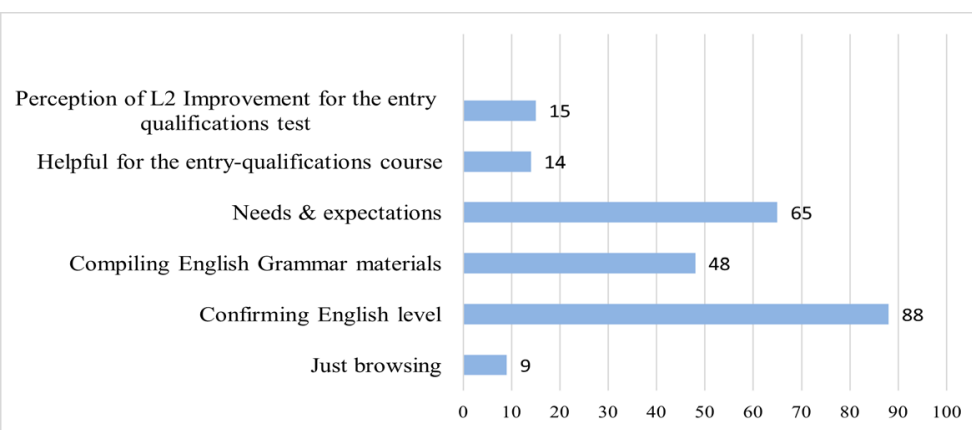

Figure 3 Results of Participants' Intentions (LMOOC 2017)

although for just a few the course was helpful for the entry-qualifications course. Finally, around half of participants opted for compiling English Grammar materials as their initial intention to take the course.

Next, more informative questions were asked regarding course contents in a similar fashion. The students' responses for the 6 informative statements deal with their perceptions about course contents, as shown in Figure 4. As a means to measure their responses, we assigned 1 for each selected statement and 0 when the statement was not selected. For the total score: most participants selected "English grammar" or "Contrastive Grammar" (English-Spanish) as their favorite content for MOOC; a lot of them selected "CLIL modules" or "ESP contents"; whereas just a half of participants preferred to use printed copies of "grammar textbook" or "ESP textbook".

\section{LMOOC-2020 Results}

Over 120 students (out of 1,200 course participants) responded to the questionnaire in the special edition of the LMOOC launched during the COVID19 pandemic in 2020. This time, they were not encouraged to answer the questionnaire but were allowed to freely answer the 12 questions raised in the final survey, as their peers had done in 2017.

As with the previous group, we could obtain relevant information on participants' intentions after having taken the brief course. Figure 5 displays the total score. Most of participants chose "confirming their English level", whereas very few selected "just browsing the course". About half of them chose "having met their L2 needs and course expectations" or "compiling English grammar materials". Just a few chose "L2 improvement for the entry-qualifications test or "helpful for the entry-qualifications test".

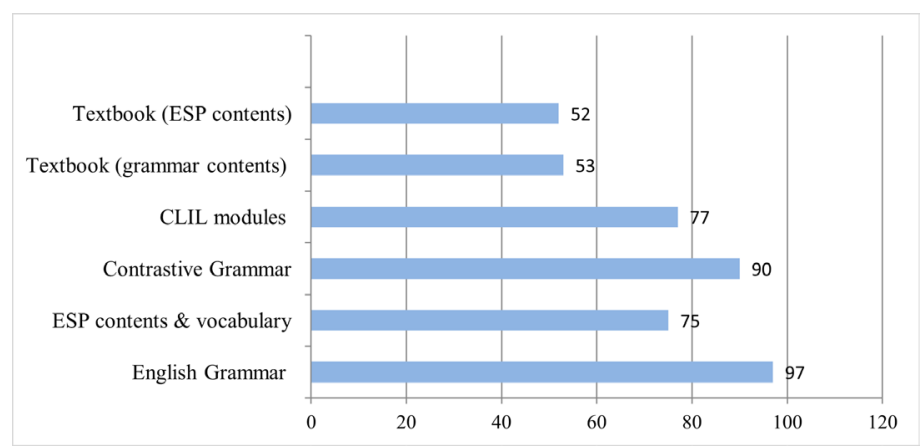

Figure 4 Results of Participants' Interest on Contents (LMOOC 2017) 


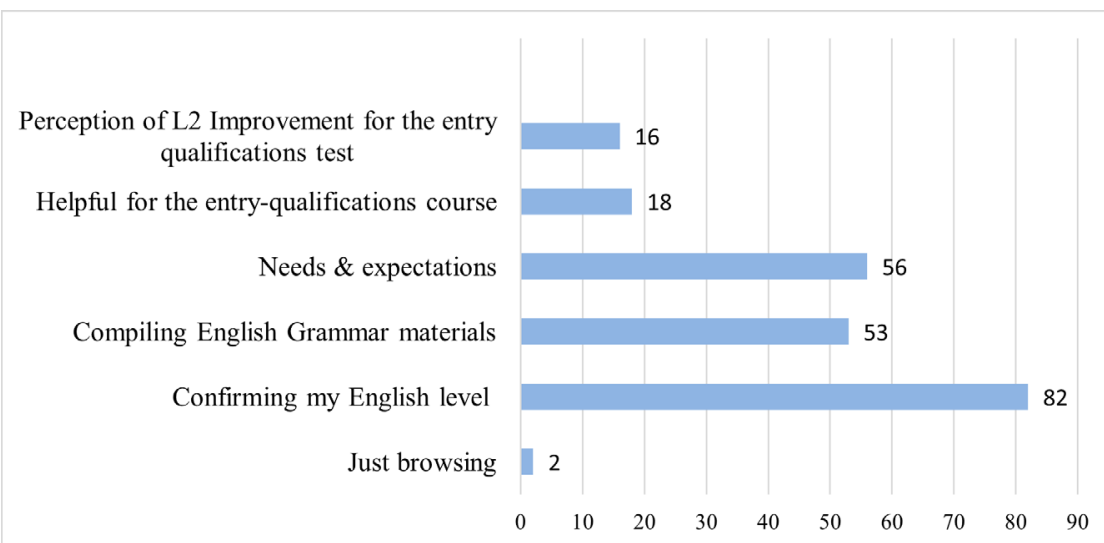

Figure 5 Results of Participants' Intentions (LMOOC 2020)

In addition, the same participants could freely rate this type of LMOoc. In this new course, participants were presented with six similar informative statements regarding their perceptions about course content. As in the previous cases, we assigned 1 for each selected statement and 0 when the statement was not selected. As indicated in Figure 6, below, most of participants selected "English grammar" or "Contrastive Grammar" (English-Spanish). More than half of them selected "ESP contents" or "CLIL modules"; less than half preferred to use a grammar textbook for standard English courses; and over a quarter of participants selected preferred to have a ESP textbook in other standard courses.
The design of a study is key to carry out the analysis of the data (Lehmann, 1992). A number of initial steps were taken so as to correctly retrieve our designed study as indicated in the following sections.

\section{Hypothesis Testing}

First of all, we examined the normality of the data of our sample obtained from our experimental materials (the questionnaire) from two different periods of time; secondly, we established the statistical differences between the two groups; and, thirdly, we established the relevant correlations between the variables that we were interested in controlling in relation to the hypotheses that we wanted to test in our study.

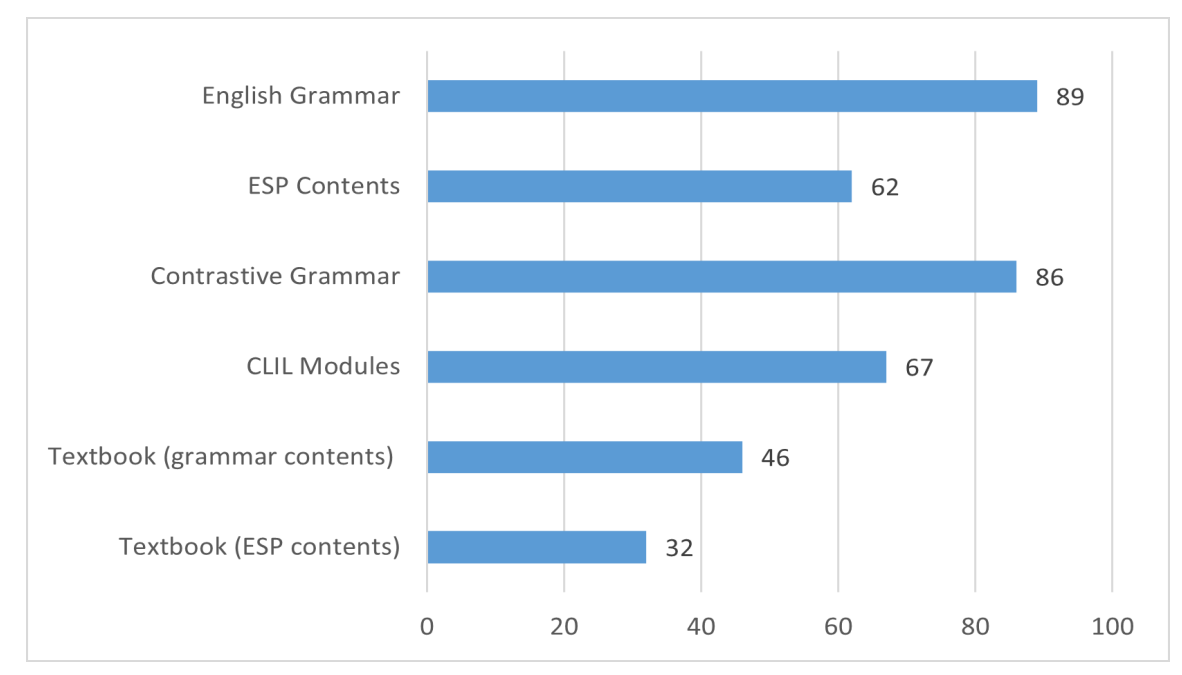

Figure 6 Participants' Interest in Contents (LMOOC 2020) 


\section{Testing Normality of the Sample}

Following Corder and Foreman (2014), we used the Kolmogorov-Smirnov (K-S) test to measure the normality of the study samples, bearing in mind that our sample size is 122 per group, which is larger than 50 . Using this test for normality of the distribution, we compared samples with a standard normal distribution. This is equivalent to setting the mean and variance of the reference distribution equal to the sample estimates.

Furthermore, the two-sample $\mathrm{K}-\mathrm{S}$ test seemed to be relevant for our nonparametric method because we wanted to compare two groups and estimate differences in both location and shape of the empirical cumulative distribution functions of our two samples. We also included the ShapiroWilk test, although it is commonly assumed to be more appropriate for sample sizes less than 50 . In either case, significance is measured by the $p$ value $>0.05$ to reject the null hypothesis and proceed with parametric testing. The results obtained from both tests concerning course satisfaction per group are indicated in Table 3.

Considering the test results above, the study samples did not follow a normal distribution since the significance value is $>0.05$ in both normality tests.

Table 3 Tests Measuring Normality

\begin{tabular}{lccccccc}
\hline & \multirow{2}{*}{ Course Year } & \multicolumn{3}{c}{ Kolmogorov-Smirnov $^{a}$} & \multicolumn{3}{c}{ Shapiro-Wilk } \\
\cline { 3 - 8 } & & Statistic & GI & Sig. & Statistic & GI & Sig. \\
\hline Course & 2017 & .469 & 122 & .000 & .535 & 122 & .000 \\
Satisfaction & 2020 & .503 & 122 & .000 & .456 & 122 & .000 \\
\hline
\end{tabular}

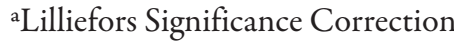

This allowed us to further compare data and keep testing the null hypothesis that the two groups show a similar distribution of data. For this purpose, we measured the sample against the study variables on intention behaviour and course content through the Whitney $\mathrm{U}$ test.

\section{Whitney UTest}

In order to measure any statistical differences between the two samples that did not correspond to normal distribution, we used the non-parametric Mann-Whitney U test (Lehmann, 2006; Corder \& Foreman, 2014). Following this test, we examined the medians of the data from each group since the dependent variable was either ordinal or continuous but not normally distributed.

In particular, we tested students' intentions regarding the LMOOC, on an ordinal scale based on course year (independent variable), with respect to the following dependent variables "Recommending the course", "Browsing the course", "Confirming English level", "Compiling English materials", "Meeting L2 needs", and "Assessing general L2 performance". The results of statistical significance are provided in Table 4 .

Table 4 Mann-Whitney U Test: Intention-Behaviour

\begin{tabular}{lccccccc}
\hline & Recommend & Browse & Confirm & Compile & $\begin{array}{c}\text { L2 } \\
\text { Needs }\end{array}$ & $\begin{array}{c}\text { L2 } \\
\text { Performance }\end{array}$ & $\begin{array}{c}\text { Course } \\
\text { Performance }\end{array}$ \\
\hline U de Mann-Whitney & 7320.00 & 7076.00 & 7198.00 & 7137.00 & 5612.00 & 738.00 & 7198.00 \\
W de Wilcoxon & 14823.00 & 14579.00 & 14701.00 & 14640.00 & 13115.00 & 14884.00 & 14701.00 \\
Z & -.321 & -1.773 & -.560 & -.649 & -3.897 & -.192 & -.757 \\
Asymp. Sig (2-tailed) & .748 & .076 & .575 & .517 & .000 & .848 & .449 \\
\hline
\end{tabular}

Independent variable: Course year 
Table 5 Mann-Whitney U Test: Perceptions on Course Content

\begin{tabular}{lcccccc}
\hline & $\begin{array}{c}\text { English } \\
\text { Grammar }\end{array}$ & EsP Content & $\begin{array}{c}\text { Contrastive } \\
\text { Analysis }\end{array}$ & cll & $\begin{array}{c}\text { ESP } \\
\text { practice }\end{array}$ & Textbook \\
\hline U de Mann-Whitney & 6954.00 & 6649.00 & 7062.00 & 6832.00 & 7015.00 & 7442.00 \\
$\begin{array}{l}\text { W de } \\
\text { Wilcoxon }\end{array}$ & 14457.00 & 14152,00 & 14565,00 & 14335.00 & 14518.00 & 14945.00 \\
Z & -1.201 & -1.674 & -.855 & -1.299 & -.911 & .00 \\
$\begin{array}{l}\text { Asymp. Sig } \\
\text { (2-tailed) }\end{array}$ & .230 & .094 & .393 & .194 & .362 & 1.00 \\
\hline
\end{tabular}

* Independent variable: Course year

The test results indicated above show that we only obtained a significant difference in just one case, namely, the distribution of the variable of "meeting student's L2 needs". Note that the Mann-Whitney $\mathrm{U}$ test also indicated that this was statistically significant: $U(N 2017=122 N 2020=122)=5612$, $\mathrm{z}=-3.89, \mathrm{p}<.000)$.

Furthermore, we proceeded to make a verification regarding students' perceptions on course content and materials. In particular, our dependent variables were "English grammar", "ESP content", "Contrastive Analysis", "CLIL", “ESP practice", and "Textbook activities", "meeting L2 needs", and "assessing general L2 performance (L2 improvement)", whereas the independent variable was again "course year: 2017 and 2020". The results of statistical significance appear in Table 5.

Considering the statistical data above, this time, we did not find any significant differences between groups, given that for all dependent variables on course content we obtained $\mathrm{p}>0.5$. Hence, we could not reject the null hypothesis that there were no differences between groups.

\section{Correlation}

As we saw in the previous section, only the variable of "L2 needs" showed a significant difference between year groups. Therefore, it is worth asking if there is a correlation between this variable and the sociological environment in which the students took the LMOOC, both in 2017 and in the special course during the COVID-19 pandemic. According to the K-S test, there was not a normal distribution, and therefore, we needed to use the Spearman Rho correlation test, following Corder and Foreman (2014) for similar designs. The test results are shown as in Table 6.

Table 6 Rho Spearman: Intention-Behaviour (L2 Needs)

\begin{tabular}{lcc}
\hline \multicolumn{1}{c}{ Rho-Spearman } & Course Year & L2 Needs \\
\hline Correlation & 1.00 & $.250^{*}$ \\
Significance (2-tailed) &. & .000 \\
$\mathrm{n}$ & 244 & 244 \\
\hline
\end{tabular}

${ }^{*}$ correlation is significant at the level 0.01 (2-tailed).

In order to correctly interpret the Rho-Spearman test results above, we considered coefficient values. We followed the common assumption that if they were close to 1 , they indicated a strong and positive correlation. Values close to -1 could instead indicate a strong and negative correlation. Values close to zero would imply that there might be another type of correlation, but not a linear one. The results of coefficient values per both groups are provided in Figure 7.

Since our design was based on a binary response: 1 was the response obtained by those students who showed to have met their L2 needs, whereas 0 was the response obtained from those students who did not answer or who considered not to have met 


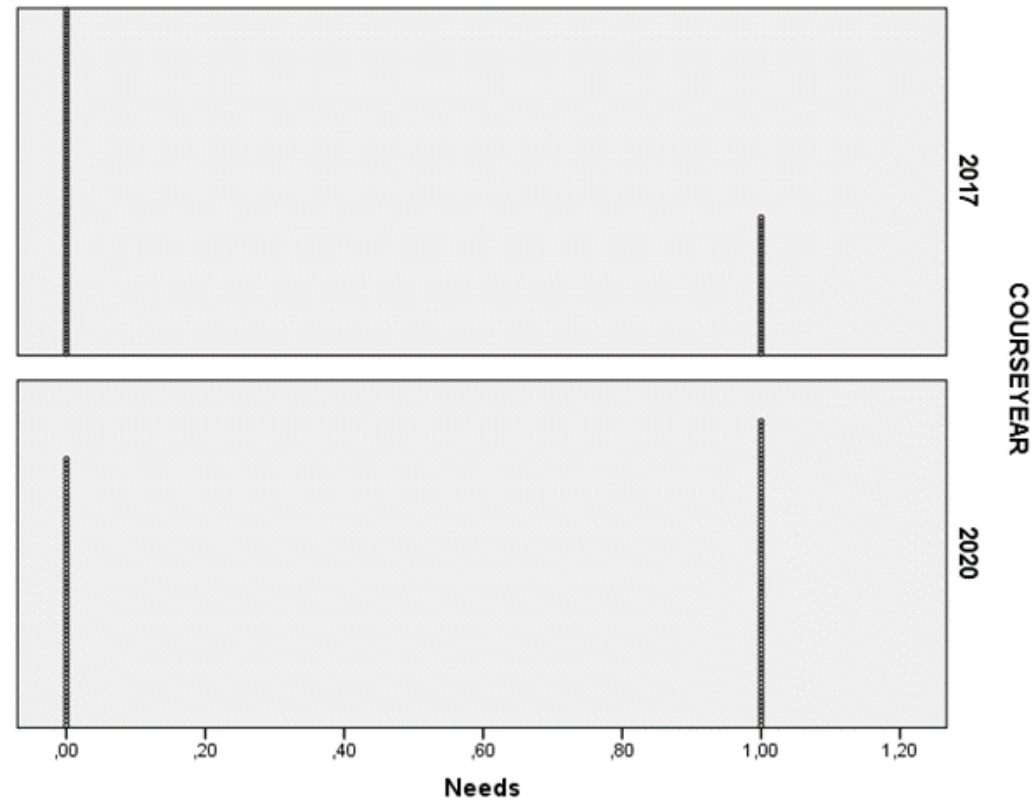

Figure 7 Rho-Spearman Correlation \& Intention-Behaviour (L2 Needs)

them. The fact that there was a positive linear correlation in the second group, as indicated in Figure 7 above, led us to assume that this dependent variable was only relevant for this group.

\section{Discussion and Conclusions}

The study suggests that Moocs are quite supportive when developing some particular learning skills in special-need situations like the Covid19 pandemic. As for the main research question dealing with the intention-behaviour gap, some insightful responses were also obtained. For example, one of the motivations that led students to enroll in the LMOOC was to learn about language strategies to succeed in the entry-qualifications test which would allow them to enter university. However, the motivations for students were not limited to test strategy use.

In the case of the variable regarding student L2 needs, we found a significant difference between groups. The learners that took the LMOoc during the COVID-19 pandemic in 2020 did not score this variable as high as their peers in the group of students that took the LMOOC in 2017. This significant difference suggested that under severe circumstances, participants were more demanding regarding their own learning processes. As for the answers to the question regarding the type of English courses that seem to be more appropriate for adult learners, we did not obtain any significant differences between groups. In both groups, the expectation to find English grammar when taking up English courses was highly scored. They also rated vocabulary and practice in ESP as quite useful. Therefore, we may conclude that language teachers should be aware of the importance of ESP at these elementary levels because adult learners seem to require this specific expertise in their second language primarily for their current and future careers.

However, the question on whether English courses should be based on a traditional approach to English grammar with practice in the use of English for general purposes, or rather a course based on English for specific purposes regarding different fields of study at the university requires further research. Language teachers could obtain very relevant information from students by doing research on more innovative LMOocs; 
consequently, these brief online courses may be an important tool at any moment to support other formal course settings.

Other examined results from the questionnaire (conducted under two very different circumstances) helped to depict learners' intention for this type of course. The research questions addressed the human need to learn in addition to the L2 needs of students and the appropriate resources necessary to optimize academic performance in both ordinary and pandemic situations. The motivations for students were not limited, since the LMOOC was open to students who could have different needs or course intentions. In fact, the LMOOC launched in both years also attracted many adult students who stated to be willing to learn English as a second or foreign language in general. New research studies could shed some light on how English courses should be addressed in extension education, especially for older students who usually have insufficient preparation in many academic aspects, due to lack of time.

As mentioned above, LMoocs may be very supportive when developing learning skills in special-need situations. We might also surmise that under severe pandemic circumstances, participants were more critical of their own learning processes. Moreover, a measurement of the intention-behaviour gap also produced insightful responses particularly relevant for practitioners and policy makers concerned with educational outcomes. From this type of responses in other future courses, language teachers could obtain very relevant information from students and therefore LMOOCs can be used as an important tool at any moment of the process of formal course development.

Finally, limitations to the present study include the sample size, specialized course contents, and teaching approach. Since students were not required to use any textbook, we cannot conclude much about this type of study material, usually found in more formal settings. Moreover, large-scale studies also ought to be conducted to reveal further correlation between perceived L2 needs and course completion. Creation of an LMOOC with the sole purpose of supporting entrance test preparation might lead to an increase in perception of L2 needs being met. Further research is necessary to identify more effective combinations of language teaching methodologies to be applied across different English-education teaching contexts. By analyzing intention-behaviour, one will better deal with educational experiences that encompass study needs, motivation, learning styles, and other social or cultural factors that affect differentiated teaching practices. MOOCs are part of the new global learning scenario and can help adopt a tailored approach to meet students' needs and interests.

\section{References}

Anders, A. (2015) Theories and applications of massive online open courses (MOOCs): The case for hybrid design. International Review of Research in Open and Distributed Learning, 16(6), 39-61. https://doi. org/10.19173/irrodl.v16i6.2185

Bárcena, E. \& Read, T. (2015) The role of modularity and mobility in language Moocs. Verbeia: Journal of English and Spanish Studies, 1, 28-35.

Bárcena, E., Martín-Monje, E., \& Read, T. (2015) Potentiating the human dimension in language Moocs. Experience Track. Proceedings of the European MOoc Stakeholder Summit (pp.4654). https://www.researchgate.net/profile/ Elena-Martin-Monje/publication/340817309_Potentiating_the_human_dimension_in_Language_ MOOCs/links/5e9f252ba6fdcca789309f3f/ Potentiating-the-human-dimension-in-LanguageMOOCs.pdf

Bargh, J. A. (2006) What have we been priming all these years? On the development, mechanisms, and ecology of nonconscious social behaviour. European Journal of Social Psychology, 36(2), 147-168. https://doi.org/10.1002/ejsp.336

Baumeister, R. F., \& Bargh, J. A. (2014) Conscious and unconscious: Toward an integrative understanding of human mental life and action. In J. W. Sherman, B. Gawronski, Y. Trope (Eds.), Dual-process theories of the social mind (pp. 35-49). Guilford Press.

Brahimi, T., \& Sarirete, A. (2015) Learning outside the classroom through moocs. Computers in Human 
Behaviour, 51, 604-609. https://doi.org/10.1016/j. chb.2015.03.013

Breslow, L., Pritchard, D. E., DeBoer, J., Stump, G. S., Ho, A. D., \& Seaton, D. T. (2013) Studying learning in the worldwide classroom: Research into edX's first Mooc. Research \& Practice in Assessment, 8(1), $13-25$.

Canole, G. (2016) Moocs as disruptive technologies: strategies for enhancing the learner experience and quality of MOocs. Revista de Educación a Distancia (RED), 50(2). https://doi.org/10.6018/red/50/2

Carrió-Pastor, M. L. \& Mestre Mestre, E. M. (2014). Motivation in second language acquisition. Procedia - Social and Behavioral Sciences, 116, 240-244. https://doi.org/10.1016/j.sbspro.2014.01.201

Castrillo de Larreta Azelain, M. D, Martín-Monje, E. \& Vázquez-Cano, E. (2018). Guía práctica para el diseño y tutorización de Mooc. Telefónica Educación Digital.

Castrillo de Larreta Azelain, M. D. (2015) Language teaching in Moocs: The integral role of the instructor. In E. Martín-Monje \& E. Bárcena (Eds.), Language MOoCs: Providing learning, transcending boundaries (pp. 67-90). De Gruyter Open.

Christensen, G., Steinmetz, A., Alcorn, B., Bennett, A., Woods, D., \& Emanuel, E. J. (2013). The MOoc phenomenon: Who takes massive open online courses and why? SSRN Electronic Journal. https:// doi.org/10.2139/ssrn.2350964

Corder, G. W.; Foreman, D. I. (2014). Nonparametric statistics: A step-by-step approach. Wiley.

Escobar M. A. (2020). Developing CLIL in tertiary education: Working with tourism texts. In K. Nalan, E. Isik-Tas, \& H. Jian (Eds.), English for specific purposes instruction and research: Current practices, challenges and innovations (pp. 269-288). Palgrave Macmillan. https://doi.org/10.1007/978-3-030-32914-3_14

Escobar, M. A; da Cunha, I; Gonzalez-Mingez, M. T.; Luzondo, A. (2020). Curso de inglés para adultos $\left(2{ }^{2}\right.$ Ed.). UNED publicaciones.

Escobar, M. A., Ciancio, J., da Cunha, I., \& Luzondo, A. (2017). LMOoc: Gramatica inglesa para curso de acceso. https://canal.uned.es/ series/5a6f2dbeb1111f347a8b4569

Escobar, M. A., da Cunha, I. (2018). Designing writing materials for tourism text genres through technological tools. In L. Hurajová, G. Chmelíková, \& N. Stojkovic (Eds.), Convergence of ESP with other disciplines (pp.1-18). Vernon Press.
Gil-Jaurena, I., Callejo-Gallejo, J. Agudo, Y. (2017). Evaluation of the UNED MOOCs implementation: Demographics, learner opinions, and completion rates. International Review of Research in Open and Distributed Learning, 18(7), 141-168. https://doi. org/10.19173/irrodl.v18i7.3155

Grünewald, F., Meinel, C., Totschnig, M. \& Willems, C. (2013). Designing Moocs for the support of multiple learning styles. In D. Hernández-Leo, T. Ley, R. Klamma y A. Harrer (Eds.), Scaling up learning for sustained impact (pp. 371-382). Springer. https:// doi.org/10.1007/978-3-642-40814-4_29

Gütl, C., Rizzardini, R. H., Chang, V., \& Morales, M. (2014). Attrition in MOoc: Lessons learned from drop-out students. In L. Uden, J. Sinclair, Y.-H. Tao, \& D. Liberona (Eds.), Learning technology for education in cloud. MOOC and big data (pp. 37-48). Springer. https://doi.org/10.1007/978-3-319-10671-7_4

Hakim, B. (2020). Technology integrated online classrooms and the challenges faced by the EFL teachers in Saudi Arabia during the COVID-19 pandemic. International Journal of Applied Linguistics \& English Literature; Footscray, 9(5), 33-39. https://doi. org/10.7575/aiac.ijalel.v.9n.5p.33

Hew, K. F., \& Cheung, W. S. (2014). Students' and instructors' use of massive open online courses (MOOCs): Motivations and challenges. Educational Research Review, 12, 45-58. https://doi.org/10.1016/j. edurev.2014.05.001

Hutchinson, T. \& Waters, A. (1987). English for specific purposes. A learning-centred approach. Cambridge University Press. https://doi.org/10.1017/ CBO9780511733031

Jung, E., Kim, D., Yoon, M., Park, S., Oakley, B. (2019). The influence of instructional design on learner control, sense of achievement, and perceived effectiveness in a supersize MOOC course. Computers \& Education, (128), 377-388. https://doi.org/10.1016/j. compedu.2018.10.001

Kenny, N., \& Escobar, L. (Eds.). (2020). The changing face of ESP in today's classroom and workplace. Vernon Press.

Kenny, N., Isik-Tad, E., \& Huang J. (2020). English for specificpurposes instruction and research: Currentpractices, challenges and innovations. Palgrave Macmillan. https://doi.org/10.1007/978-3-030-32914-3

Koller, D., Ng, A., Do, C., \& Chen, Z. (2013). Retention and intention in massive open online courses. EDUCAUSE Review. https://er.educause.edu/articles/2013/6/ retention-and-intention-in-massive-open-onlinecourses-in-depth 
Kuhl, J. \& Quirin, M. (2011). Seven steps toward freedom and two ways to lose it: Overcoming limitations of intentionality through self-confrontational coping with stress. Social Psychology, 42(1), 74-84. https:// doi.org/10.1027/1864-9335/a000045

Lehmann E. L. (1992). Introduction to Neyman and Pearson (1933) On the problem of the most efficient tests of statistical hypotheses. In S. Kotz \& N. L. Johnson (Eds.), Breakthroughs in Statistics, 1, Springer Verlag. https://doi.org/10.1007/978-1-4612-0919-5_5

Liyanagunawardena, T. R., Williams, S. A. (2016, January 7). Elderly learners and massive open online courses: A review. Interactive Journal of Medical Research, 5(1), el. https://doi.org/10.2196/ijmr.4937

Loizzo, J., Ertmer, P. A., Watson, W. R., Watson, S. L. (2017). Adult MOoc learners as self-directed: Perceptions of motivation, success, and completion. Online Learning, 21(2). https://olj.onlinelearningconsortium. org/index.php/olj/article/view/889/271

Martín-Monje, E., Bárcena, E. (eds.) (2014). Language MOOCs: Providing Learning, Transcending Boundaries. De Gruyter Open.

Mengual-Andrés, S., \& Payà Rico, A. P. (2018). Open educational resources' impact and outcomes: The essence of open knowledge and its social contribution. Education Policy Analysis Archives, 26(119). http:// dx.doi.org/10.14507/epaa.26.3667

Pankowska, M. B. (2017). Moocs as supplement of informal education. International Journal of E-Adoption, $9(1), 10-25$.
Pilli, O. \& Admiraal, W. (2016) A. taxonomy of massive open online courses. Contemporary Educational Technology, 7(3), 223-240.

Sheeran, P., \& Web T. L. (2016). The intention-behaviour gap. Social and Personality Psychology Compass, 10(9), 503-518.

Siemens, G. (2005). Connectivism: A learning theory for the digital age. International Journal of Instructional Technology \& Distance Learning, 2, 3-10. http:// www.itdl.org/Journal/Jan_05/article01.htm

Thompson, G., \& Mckinley, J. (2018). Integration of content and language learning. In J. I. Liontas, M. DelliCarpini, \& S. Abrar-ul-Hassan (Eds.), TEsol. Encyclopedia of English Language Teaching. Wiley.

Torres, W. J., \& Beier, M. E. (2018) Adult development in the wild: The determinants of autonomous learning in a massive open online course. Learning and Individual Differences, 65, 207-217.

Universities UK. (2013). Massive open online courses: Higher education's digital moment? Author. https://www. universitiesuk.ac.uk/policy-and-analysis/reports/ Documents/2013/massive-open-online-courses.pdf

Walker, T. (2018). 'Who are our learners? A research based insight into FutureLeaerners' In N. O'grady (ed.) Newsletter content. Retrieved from https://www. futurelearn.com/info/press/research-insights/ learners-part-1

Wedemeyer, C. A. (1973). Characteristics of open learning systems. Report of NAEB advisory committee on open learning systems to NAEB conference. New Orleans, LA. http://files.eric.ed.gov/fulltext/ED099593.pdf 


\section{Appendix}

\section{Full Questionnaire (Spanish \& English)}

Instructions (In Spanish): ¿Cuáles de estas intenciones iniciales cree que se han cumplido? (puede elegir varias opciones) /"Which of these initial intentions do you think have met? (you can select several options)"

Part 1. General Satisfaction \& Recommendation

1. El curso ha cumplido mis expectativas para comprender la gramática necesaria para el examen de acceso a la universidad

"The course has met my expectations to understand the necessary grammar for the entry qualifications test."

2. Recomendaré este mooc a familiares, amigos y conocidos

"I will recommend this mooc to family, friends and acquaintances."

\section{Part 2. Student Intentions and Perceptions After Taking the Course}

1. He "curioseado", aunque no he visto los materiales y actividades en profundidad

"I have "browsed", although I have not seen the materials and activities in depth."

2. He comprobado mis conocimientos de inglés

"I have confirmed my level of English."

3. He recopilado materiales referentes a la gramática inglesa

"I have compiled materials on English Grammar."

4. He completado el curso y sacado el mayor provecho del mismo de acuerdo con mis necesidades: "I have completed the course and made the best of it according to my L2 needs."

5. Mis resultados de inglés han mejorado en el Curso de Acceso

"I have improved my results in English in the entry-qualifications course."

6. He mejorado mi inglés para aprobar el examen de Acceso a la Universidad

"I have improved my English to pass the entry qualifications test."

\section{Part 3. Course Contents}

Instructions (in Spanish): Agradeceríamos su opinión sobre las siguientes afirmaciones

"We would appreciate your opinion on the following statements."

7. Los cursos de inglés de acceso a la universidad deberían principalmente enfocarse en aspectos gramaticales.

"University access English courses should primarily address grammar issues."

8. Los cursos de inglés para el acceso a la universidad deberían contener vocabulario y contenidos específicos sobre las distintas disciplinas: derecho, matemáticas, ingeniería, etc. 
"English courses for the entry qualifications test should contain vocabulary and specific content on the different disciplines: law, mathematics, engineering, etc."

9. Los cursos de inglés para el acceso a la universidad deberían explicar los contrastes gramaticales que existen entre el inglés y el español

"English courses for the entry qualifications test should explain the grammatical contrasts between English and Spanish."

10. Los cursos de inglés para el acceso a la universidad deberían ayudar a los estudiantes a poder familiarizarse con la práctica de las distintas profesiones en la lengua inglesa.

"English courses for university access should help to introduce you to the practice of the different professions in the English language."

11. El libro titulado Curso de inglés para adultos de la uned me está ayudando a estudiar la gramática inglesa.

"The textbook titled "English Course for Adults" from uned is helping me study the English grammar."(ONLY APPLIES FOR THOSE ENROLLED IN THE ENTRY QUALIFICATIONS COURSE)

How to cite this article: Escobar Álvarez, M. A., \& Ciancio, J. (2021). Spanish adult students' intention-behaviour towards MOoc during the Covid-19 pandemic. Íkala, Revista de Lenguaje y Cultura, 26(3), 531-551. https://doi.org/10.17533/udea.ikala.v26n3a04 
